\title{
ЕКОНОМІКА
}

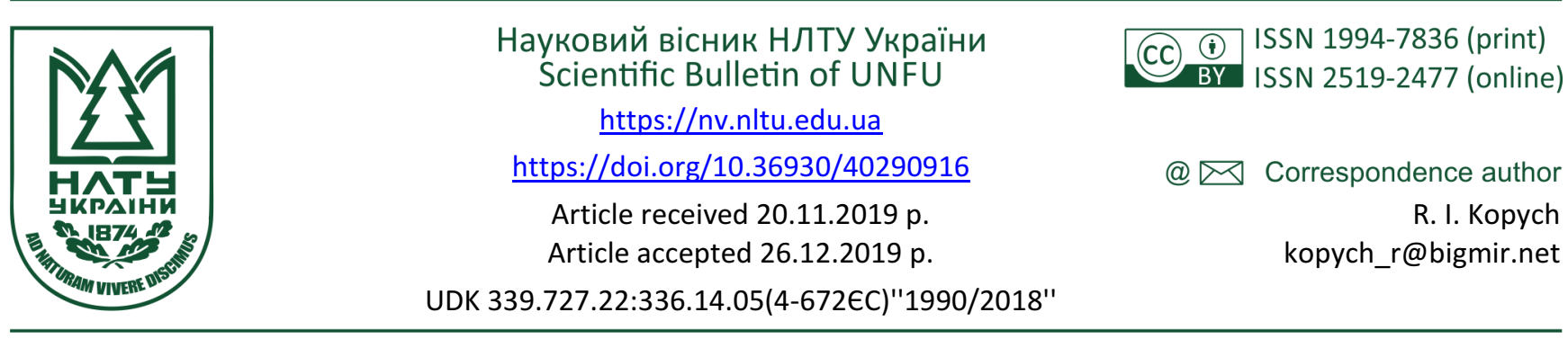

P. I. Копич

Львівський національний університет ім. Івана Франка, м. Львів, Україна

\section{ВПЛИВ ПОТОКІВ КАПІТАЛУ НА САЛЬДО БЮДЖЕТУ КРАЇН ЄВРОПЕЙСЬКОЇ "ПЕРИФЕРІЇ"}

\begin{abstract}
Зв'язок між потоками капіталу і сальдо бюджету становить важливий елемент дослідження фіскальної політики країн інтеграційного утворення, включно з особливостями взаємодії його найбільших країн та країн умовної "периферії". Насамперед доречно порівняти залежність від потоків капіталу та обмежень платіжного балансу країн Центрально-Східної Європи і Балтії, оскільки ці країни відрізняються за рівнем доходу, особливостями політики обмінного курсу та підходами до євроінтеграційного процесу. Припускається, що з підвищенням ступеня економічної інтеграції підсилюється залежність від потоків капіталу та обмежень платіжного балансу, що порівняно самостійно впливає на проведення фіскальної політики. Водночас поглиблення інтеграції призводить до уніфікації найбільш загальних параметрів фіскальної політики, як сальдо бюджету та рівень державного боргу, що полегшує гармонізацію фіскальної політики на рівні інтеграційного утворення. На підставі річних даних 1990-2018 рр. проаналізовано залежність сальдо бюджету країн Центральної і Східної Свропи, Південної Європи і Балтії від припливу капіталу і ставки LIBOR (англ. London Interbank Offer Rate). Показано, що залучення іноземного капіталу призводить до погіршення сальдо бюджету країн європейської "периферії", але вплив зникає з урахуванням циклу ділової активності, що засвідчує проциклічність потоків капіталу. Для нейтралізації надмірного припливу-відпливу капіталу, що так чи інакше впливатиме на фіскальні показники, необхідні заходи координації фіскальної політики на обох рівнях - національному і наднаціональному.
\end{abstract}

Ключові слова: фіскальна політика; дефіцит бюджету; мобільність капіталу; LIBOR; країни Центральної та Східної Європи.

Вступ. Моделювання внутрішніх і зовнішніх ефектів фіскальної політики істотно залежить від припущень щодо мобільності капіталу, що, зі свого боку, має безпосередній стосунок до функціонування економіки в інтеграційному утворенні. Якщо моделі фіскальної політики зразка 1960-1980-х років переважно містили лише ефекти зовнішньої торгівлі, а врахування потоків капіталу обмежувалося змінами процентної ставки або портфеля, то на сьогодні найбільшу увагу привертають міжчасові ефекти у приватному і державному секторах та механізми мінімізації ризику, що надає більшої ваги питанням взаємодії країн з відмінними структурними характеристиками, а в ширшому розумінні створює підстави для гармонізації фіскальної політики в рамках інтеграційного утворення. Необхідні міркування зручно розглянути на прикладі країн європейської "периферії" 3 відмінним рівнем доходу та особливостями політики обмінного курсу і підходів до інтеграційного процесу.

Матеріали і методи дослідження. Об'єктом дослідження є ефекти фіскальної політики, а предметом дослідження є взаємозв'язок між потоками капіталу і сальдо бюджету, що має безпосередній стосунок до

функціонування економіки в інтеграційному утворенні.

Метою дослідження обрано вивчення зв'язку між потоками капіталу і сальдо бюджету для країн європейської "периферії". Насамперед доречно порівняти відповідні залежності для країн Центральної і Східної Європи (ЦСЄ) та Балтії, з одного боку, і "проблемних" країн Південної Свропи, з іншого, які в 2010-2013 рр. опинилися в епіцентрі боргової кризи країн єврозони.

Завданнями дослідження є охарактеризувати динаміку сальдо бюджету досліджуваних країн та проаналізувати залежність цього показника від ставки LIBOR i сальдо фінансового рахунку.

Аналіз літературних джерел. Однією з особливостей країн ЦСС стало погіршення сальдо бюджету напередодні вступу до ЄС (2004р.), передусім у країнах "люксембурзької" групи, які мали високий дефіцит бюджету, що на третину перевищував показники країн "хельсінської" групи і майже вдвічі - країн Балтії (рис. 1). Нагадаємо, що для більшої інформативності країни ЦСС поділено на дві групи: "люксембурзьку" і "хельсінську", що відрізняються за хронологією вступу до ЄС. Початок процедури приєднання до ЄС Естонії,

\section{Інформація про автора:}

Копич Роман Іванович, канд. екон. наук, доцент, кафедра міжнародного економічного аналізу і фінансів. Email: kopych_r@bigmir.net

Цитування за ДСТУ: Копич Р. І. Вплив потоків капіталу на сальдо бюджету країн Європейської "периферії". Науковий вісник НлТУ України. 2019, т. 29, № 9. С. 92-98.

Citation APA: Kopych, R. I. (2019). The impact of capital flows on the budget balance of european periphery. Scientific Bulletin of UNFU, 29(9), 92-98. https://doi.org/10.36930/40290916 
Польщі, Словенії, Чехії та Угорщини було ініційовано на березневому (1998 р.) саміті СС в Люксембурзі. Відповідне рішення щодо Болгарії, Румунії, Словаччини, Латвії і Литви було прийнято на грудневому (1999р.) саміті ЄС у Хельсінкі. Для зручності викладу матеріалу до країн "хельсінської" групи приєднано Хорватію.

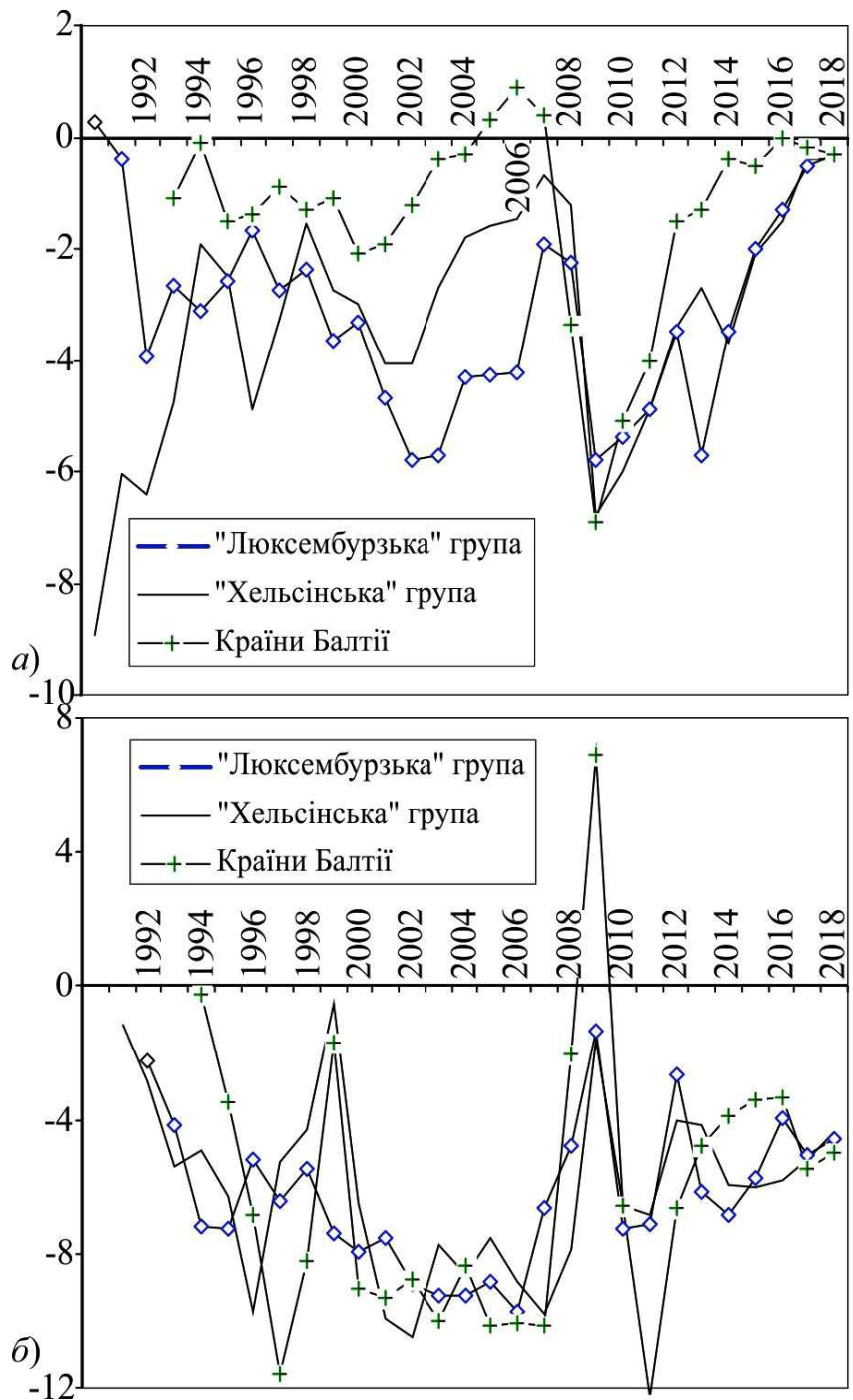

Рис. 1. Країни ЦСЄ: сальдо бюджету (\% від ВВП), 1990-

2018 рр.: a) фактичні значення; б) з урахуванням циклічної позиції. Примітка: подано середнє значення для кожної з груп країн. Джерело: World Bank

Зв'язок між погіршенням сальдо бюджету та вступом до ЄС доведено емпірично (Lewis, 2009). Сумарний експансійний імпульс оцінювали на рівні $3 \%$ від ВВП. Погіршення сальдо бюджету напередодні вступу до ЄС також зауважено в іншій праці (Schneider \& Zapal, 2005). В обох дослідженнях безпосередніми причинами послаблення фіскальної дисципліни називають особливості адаптації країн ЦСЄ до вимог членства в СС, що могло мати різноманітні пояснення: потреба податкової гармонізації, спрощення податкового менеджменту, раціоналізація сфери державного управління, завершення структурних перетворень тощо. Виглядає обгрунтованим припущення, що збільшення дефіциту бюджету відбуватиметься в розрахунку на контрастне зниження процентної ставки відразу ж після вступу до СС у поєднанні зі зниженням рівноважного значення інфляції та збільшенням припливу капіталу (Weber \& Taube, 1999, р. 25-26). Таким способом ставало можливим збільшення урядових видатків задля виконання численних вимог європейського законодавства.

3 іншого боку, вищий дефіцит бюджету можна пояснювати фіскальною "самовпевненістю", передусім у найбільших країнах 3 найвищою політичною вагою, в розрахунку на отримання коштів 3 бюджету $\mathrm{CC}$ або послаблення обмежень на зовнішні запозичення, що надавало фіскальній політиці виразного проциклічного характеру. Зазвичай приплив капіталу позначається збільшенням внутрішнього попиту та податкових надходжень, але урядові видатки зростають ще стрімкіше (Manasse, 2007, p. 455-473). Проциклічність фіскальної політики зауважено для Румунії, Латвії та Литви; у 2003-2007 pр. антициклічну фіскальну політику втілювала лише Болгарія, а у 2007 р. до неї долучилася Естонія (Christou \& Moulin, 2008, p. 47-60). За даними 20002007 рр. високу кореляцію темпів зростання урядових видатків і ВВП знайдено для Угорщини, Латвії, Литви, Польщі та Естонії, тоді як цього не було в Чехії, Румунії і Словенії (Darvas, 2009, p. 11). Після вступу до СС у країнах Балтії та Південної Європи виник надмірний попит, який посилили проциклічні підвищення заробітної плати і пенсій у державному секторі (World Economic Outlook, 2008, p. 86).

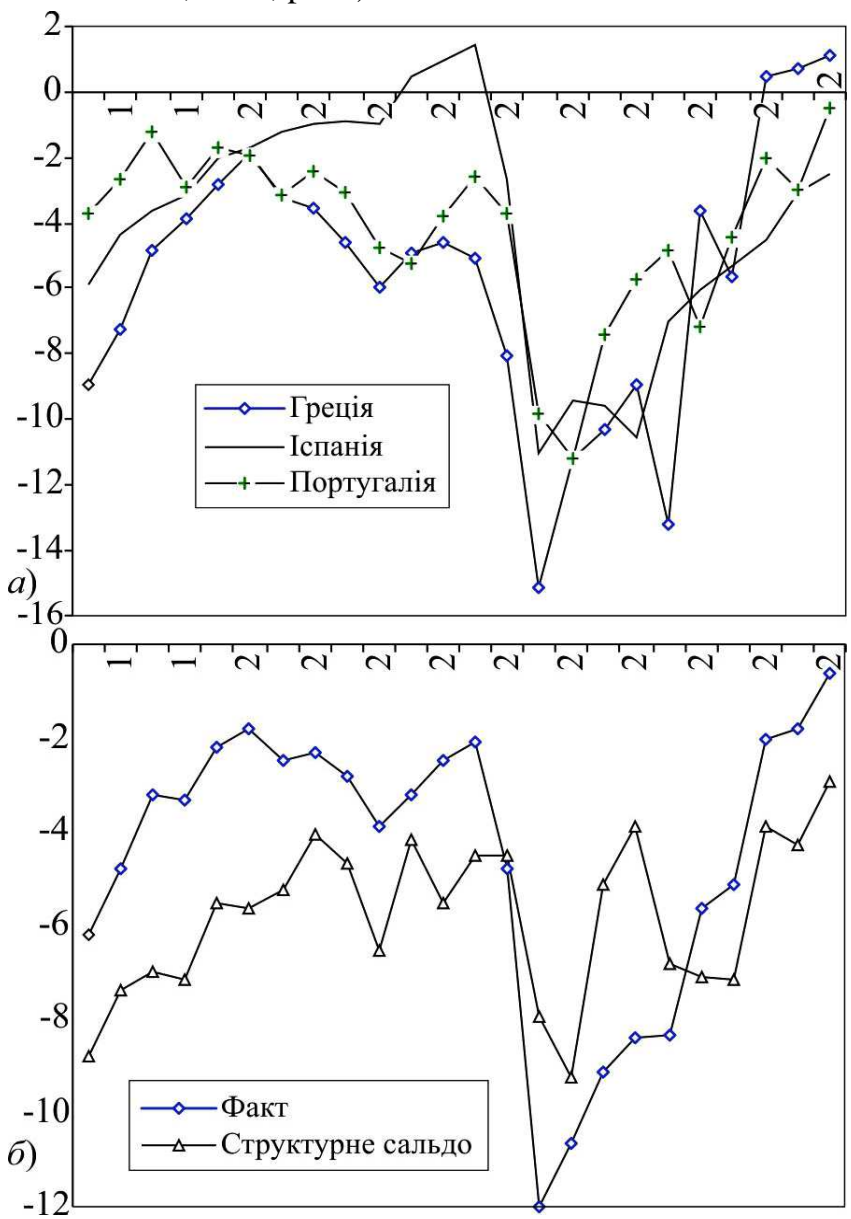

Рис. 2. Країни Південної Європи: сальдо бюджету (\% від ВВП), 1995-2018 рр.: a) окремі країни; б) середнє значення. Джерело: World Bank

"Проблемні" країни Південної Європи подібні до країн ЦСЄ у тому, що з початком світової фінансової кризи (осінь 2008 р.) відбулося істотне погіршення сальдо бюджету (рис. 2). Водночас для докризового періоду помітні істотні відмінності між Іспанією, що в 2005-2007 pр. мала профіцит бюджету, та Грецією i 
Португалією, де сальдо бюджету погіршувалося від початку декади. 3 урахуванням циклічної позиції стає очевидним, що фіскальна політика трійки "проблемних" країн загалом була експансійною. У 2009-2010 pp. фіскальні стимули були дещо вищими, ніж у країнах ЦСС, але відразу ж відбувся перехід до поліпшення сальдо бюджету. Щоправда, у 2013-2015 рр. структурний дефіцит збільшився у зв'язку зі стагнацією доходу, але вже у 2016 р. цей показник повернувся на докризовий рівень.
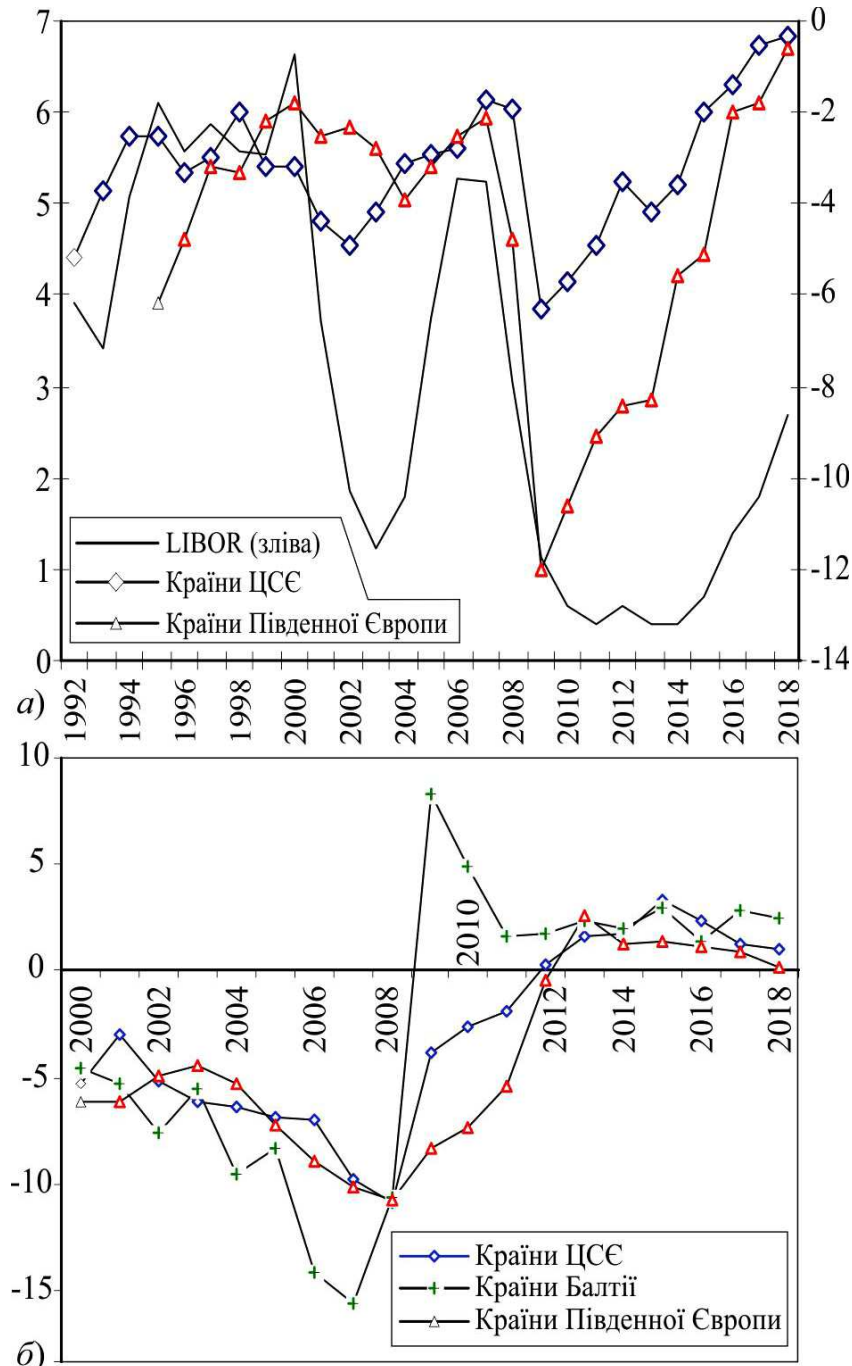

Рис. 3. Вибрані показники досліджуваних країн європейської "периферії": a) сальдо бюджету (\% від ВВП) ставка LIBOR (\%), 1992-2018 рр.; б) сальдо фінансового рахунку (\% від ВВП), 2000-2018 рр. Примітка: використано ставку LIBOR за 6-місячними позиками. Джерело: World Bank, IMF International Financial Statistics

На додаток до згаданих вище видатків на підготовку до членства в СС, окремий випадок створювало таке залучення іноземного капіталу та зниження процентної ставки на внутрішньому фінансовому ринку, що давало змогу збільшити запозичення державного і приватного секторів у розрахунку на майбутнє економічне зростання. Підстави для гіпотези про міжчасову оптимізацію створює виразний візуальний збіг траєкторій сальдо бюджету, ставки LIBOR і сальдо фінансового рахунку (рис. 3), що цілком логічно за умов високої мобільності капіталу. У такій інтерпретації погіршення сальдо бюджету країн ЦСЄ в 1999-2002 pр. зумовлено відчутним здешевленням кредитних ресурсів на зарубіжних фінансових ринках та збільшенням припливу капіталу. Нада- лі в 2003-2007 рр. сальдо бюджету поліпшувалося разом $з$ підвищенням ставки LIBOR. Після початку світової фінансової кризи стрімке погіршення сальдо бюджету в країнах ЦСЄ поєднується 3 не менш контрастним зниженням ставки LIBOR.

Результати дослідження. Якщо розглядати ставку LIBOR наближеною характеристикою потоків капіталу, то виникає відразу декілька можливостей. Потенційно приплив капіталу внаслідок здешевлення кредитних ресурсів за кордоном $(\downarrow L I B O R)$, як це передбачає модель Манделла-Флемінга (Shevchuk, 2008, pp. 323-427), можна розглядати зручною нагодою для збільшення урядових видатків, передусім за умови зниження внутрішньої процентної ставки та розширення фінансового ринку. 3 іншого боку, здешевлення кредитних ресурсів знижує кошти обслуговування державного боргу і таким способом може зменшити урядові видатки. Ще один механізм можна пояснити бажанням обмежити урядові видатки, щоб збільшити заощадження державного сектора задля профілактики надмірного погіршення сальдо поточного рахунку та пов'язаних з цим ризиків.

Податкові надходження повинні зрости в разі збільшення доходу, що передбачає обернену залежність між LIBOR та надходженнями до бюджету. Протилежне очікується, якщо збільшення податків використовується для підвищення довіри до економіки під час відпливу капіталу, який, зокрема, можна пояснити підвищенням ставки LIBOR та погіршенням різниці процентних ставок на внутрішньому і зовнішньому ринках $\left(r-r^{*}\right)$.

Візуальне враження про щільний зв'язок між сальдо бюджету та вартістю кредитних ресурсів на світовому фінансовому ринку підтримується результатами найпростішого регресійного аналізу (рис. 4). Підвищення ставки LIBOR дуже виразно асоціюється 3 поліпшенням сальдо бюджету країни Південної Свропи, меншою мірою - країн "люксембурзької" групи. Залежність слабша для країн "хельсінської" групи, а для країн Балтії їі немає взагалі. Для країн Південної Свропи кожен відсоток ставки LIBOR позначається поліпшенням сальдо бюджету на $0,5 \%$ від ВВП (як це показує коефіцієнт детермінації $R^{2}$, ставка LIBOR пояснює $19 \%$ змін сальдо бюджету).

Проте з використанням структурного сальдо бюджету пряма залежність від ставки LIBOR зникає для всіх груп країн (рис. 5), що означає проциклічність потоків капіталу (у разі підвищення ставки LIBOR та відпливу капіталу супутній спад виробництва нівелює наслідки поліпшення сальдо бюджету). Отримані результати показують, що приплив капіталу, як цього можна очікувати від зниження ставки LIBOR, може сприяти погіршенню сальдо бюджету, але водночас стимулює динаміку ВВП. Очевидно, що проблему в країнах європейської "периферії" створює проциклічність фіскальної політики, коли під час економічного зростання амплітуда поліпшення сальдо бюджету недостатня. У разі циклічного спаду виробництва це не дає змогу використати фіскальні стимули у безпечний спосіб - без надмірного збільшення державного боргу.

Залежність сальдо бюджету від LIBOR може бути ознакою ендогенності цього показника в ширшому макроекономічному контексті. Засаднича логіка полягає у 
тому, що зниження LIBOR призводить до збільшення зовнішніх запозичень для фінансування дефіциту бюджету, тоді як подорожчання кредитних ресурсів зумовлює обмеження такої практики. Помітне $з 2001$ р. зниження ставки LIBOR потенційно сприяло послабленню фіскальної дисципліни, тоді як прогнозоване подорожчання кредитних ресурсів на світових ринках матиме протилежний результат.
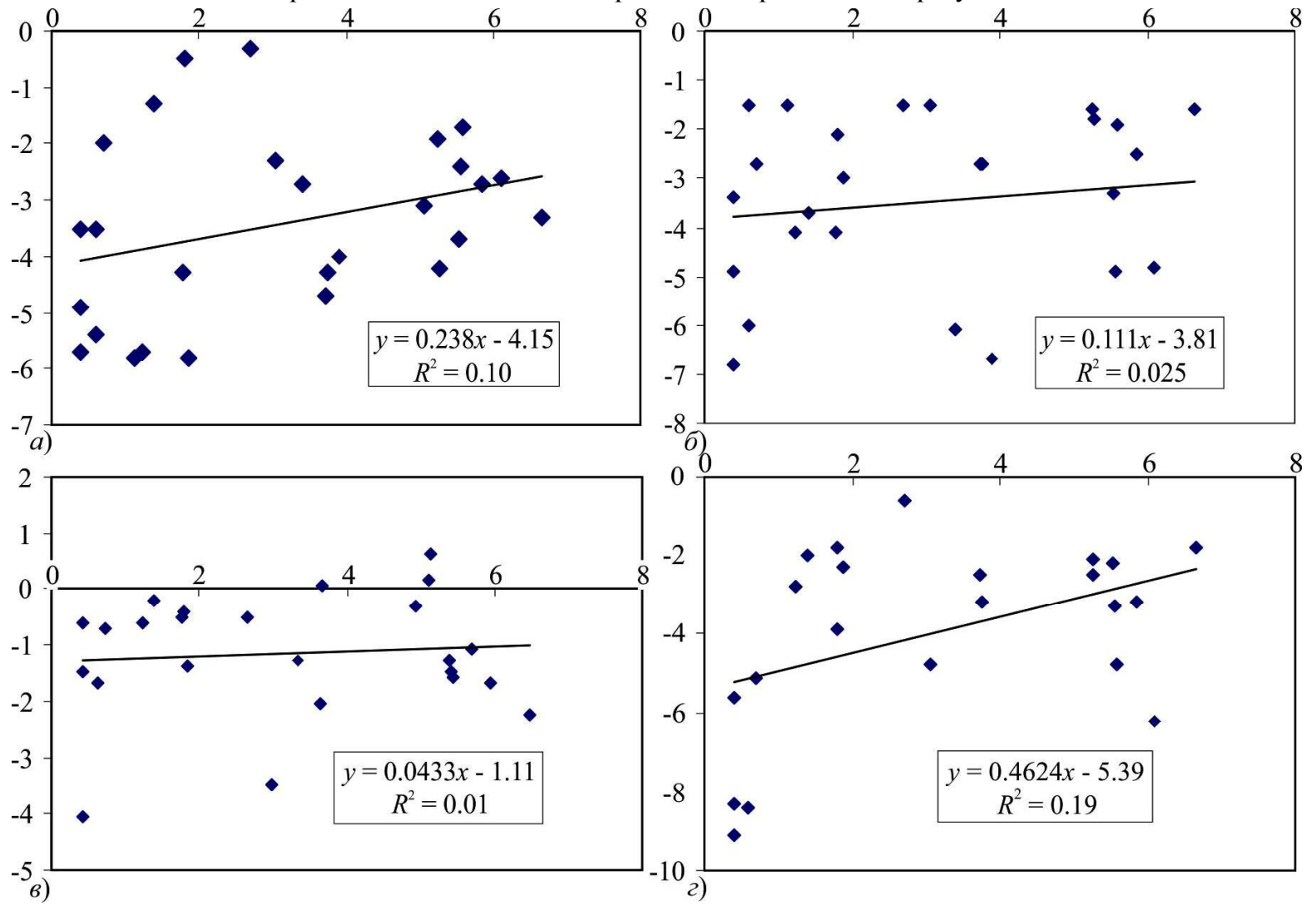

Рис. 4. Залежність сальдо бюджету від ставки LIBOR: $a$ ) країни "люксембурзької" групи; б) країни "хельсінської" групи; 6 ) країни Балтії; г) країни Південної Свропи. Примітка: на вертикальній осі подано сальдо бюджету (\% від ВВП), а на горизонтальній - ставку LIBOR (\%). Джерело: власні розрахунки
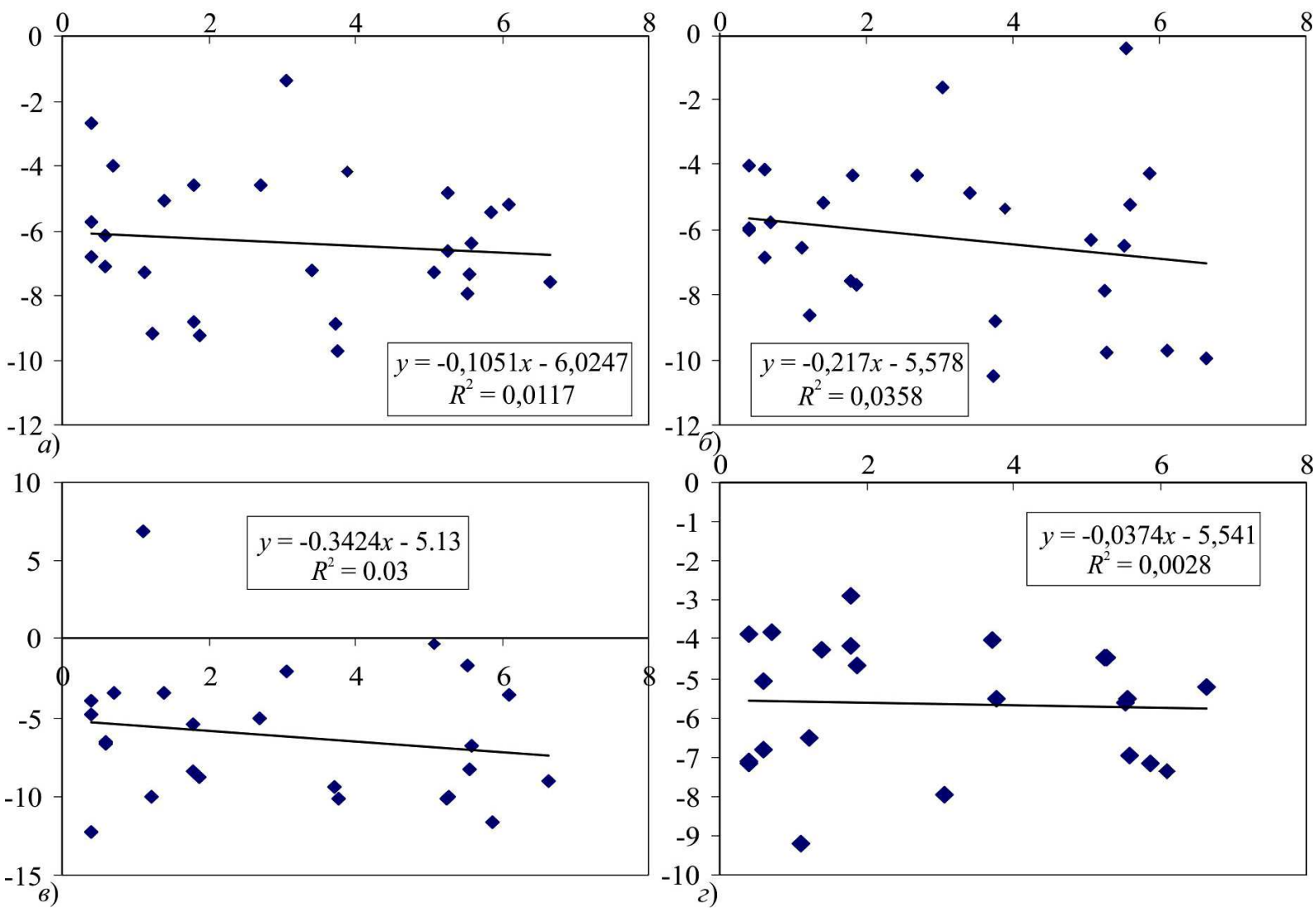

Рис. 5. Залежність структурного сальдо бюджету від ставки LIBOR: a) країни "люксембурзької" групи; б) країни "хельсінської" групи; в) країни Балтії; г) країни Південної Свропи. Джерело: власні розрахунки 
3 початком світової фінансової кризи (вересень 2008 р.) країни Балтії зазнали контрастного відпливу капіталу, а в країнах "хельсінської" групи приплив капіталу зменшився до мінімуму. Натомість у країнах "люксембурзької" групи зменшення припливу капіталу було порівняно незначним, у країнах Південної Свропи поступовим у часі (без жодних ознак "раптової зупинки", як у країнах Балтіі). Це схиляє до припущення, що висока ймовірність втрати доступу до фінансових ринків підсилює аргументацію на користь вищого рівноважного сальдо бюджету. 3 іншого боку, менший приплив капіталу може підвищити величину фіскального мультиплікатора (Barrell, Holland \& Hurst, 2012, p. 71102), а це підсилює можливості збільшення дефіциту бюджету для країн з невисоким державним боргом.

32013 р. усі країни європейської "периферії" мають відплив капіталу, що характеризує ситуацію після завершення боргової кризи в єврозоні. Низька ставка LIBOR не призвела до припливу капіталу, що заперечує поширені теоретичні аргументи щодо кращих умов фінансування дефіциту бюджету за умов рецесії та екстремально низької процентної ставки (DeLong \& Summers, 2012, p. 233-274).

Загалом виникають підстави для припущення про обернений зв'язок між потоками капіталу та поліпшенням сальдо бюджету. Така гіпотеза підтверджується емпірично (рис. 6). В усіх країнах приплив капіталу призводить до погіршення сальдо бюджету.

Кожен відсоток поліпшення сальдо фінансового рахунку позначається збільшенням дефіциту бюджету приблизно на 0,25\% від ВВП. Для країн Балтії така залежність вдвічі слабша. Якщо використати структурне сальдо бюджету, обернена залежність від припливу ка-
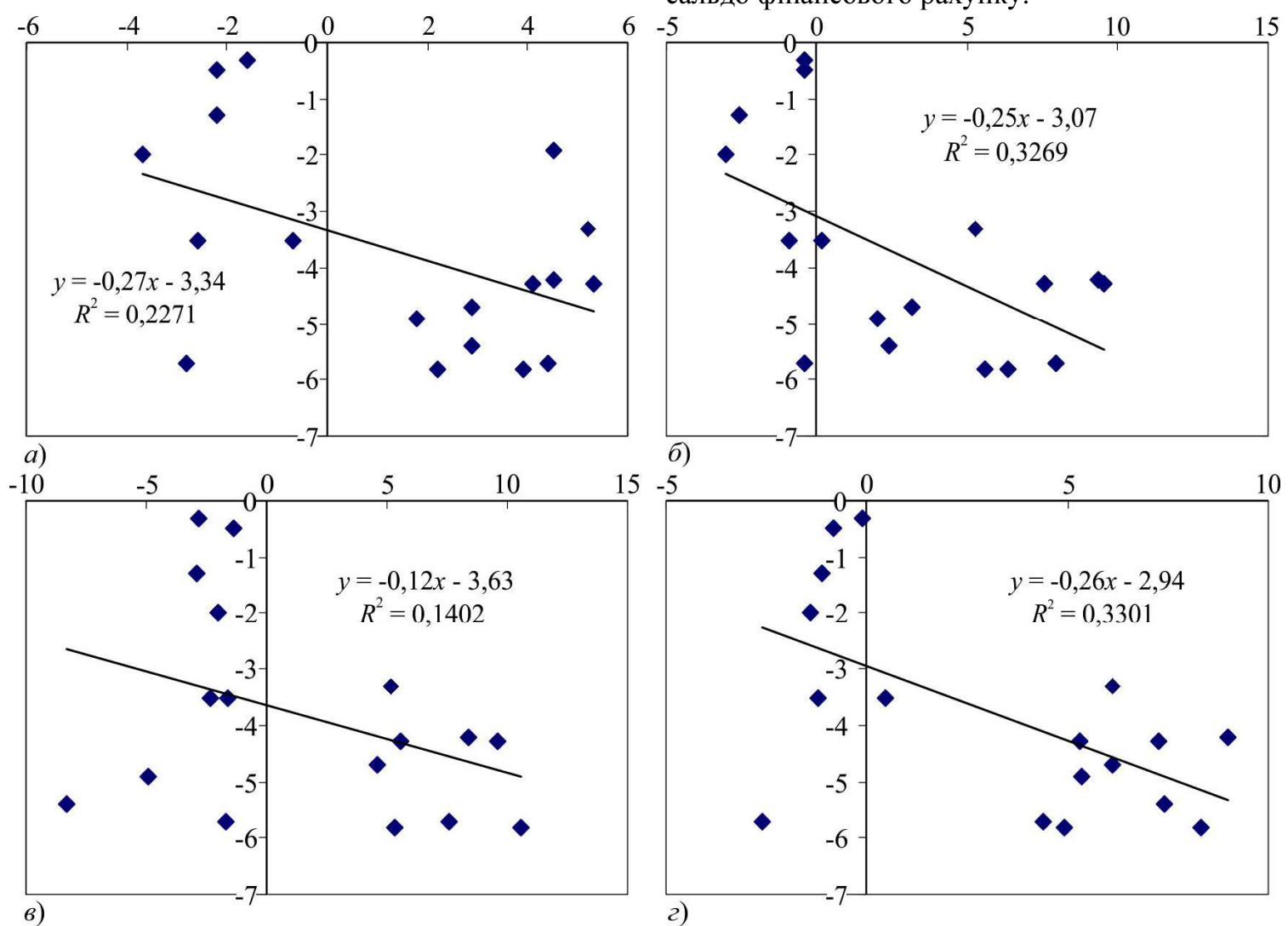

Рис. 6. Залежність сальдо бюджету від припливу капіталу: a) країни "люксембурзької" групи; б) країни "хельсінської" групи; в) країни Балтії; г) країни Південної Свропи. Примітка: на вертикальній осі подано сальдо бюджету, а на горизонтальній - сальдо фінансового рахунку (обидва показники - \% від ВВП). Джерело: власні розрахунки піталу зникає (рис. 7), що підсилює висновок щодо проциклічності потоків капіталу.

Оскільки приплив капіталу має проциклічний характер, обернена залежність сальдо бюджету від потоків капіталу - це аргумент на користь гармонізації фіскальної політики. По-перше, країни з чистим припливом капіталу мають поліпшувати сальдо бюджету і таким способом надавати фіскальній політиці необхідну антициклічність. Хоча теоретично більш сприятливе зниження RER не виключено (Obstfeld \& Rogoff, 1995, p. 624$660)$, цього не варто очікувати в економіках 3 недостатньо розвиненим фінансовим ринком. По-друге, вагомі ризики для реалізації міжчасової траєкторії сальдо бюджету може створити післякризове підвищення ставки LIBOR, яке 3 певністю погіршить умови рефінансування державного боргу. Ситуацію може погіршити тривала конвергенція процентної ставки до рівня єврозони, що підвищить ризик зворотного заміщення зовнішніх запозичень внутрішніми. По-третє, відкладення запланованого приєднання до єврозони підвищує ризик обслуговування зовнішнього боргу внаслідок майбутнього знецінення грошової одиниці як очікуваного наслідку нинішнього зовнішнього фінансування дефіциту бюджету та погіршення сальдо поточного рахунку.

Враховуючи зазначені ризики, вартує уваги досвід країн Балтії, яким вдалося послабити обернений зв'язок між сальдо бюджету і припливом капіталу. На протилежному полюсі - країни Південної Свропи, що намагалися максимально використати переваги від членства в єврозоні для збільшення дефіциту бюджету. 3 іншого боку, Естонія в 2008-2009 рр. відповідала всім необхідним макроекономічним критеріям для приєднання до єврозони, але це не запобігло стрімкому погіршенню сальдо фінансового рахунку. 


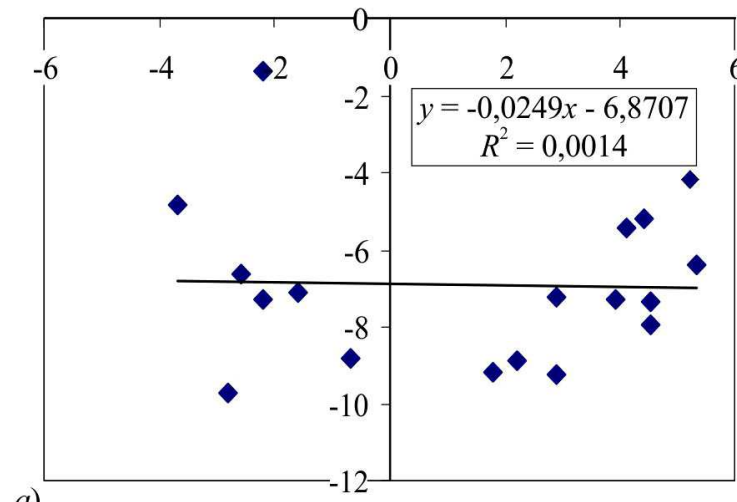

a)

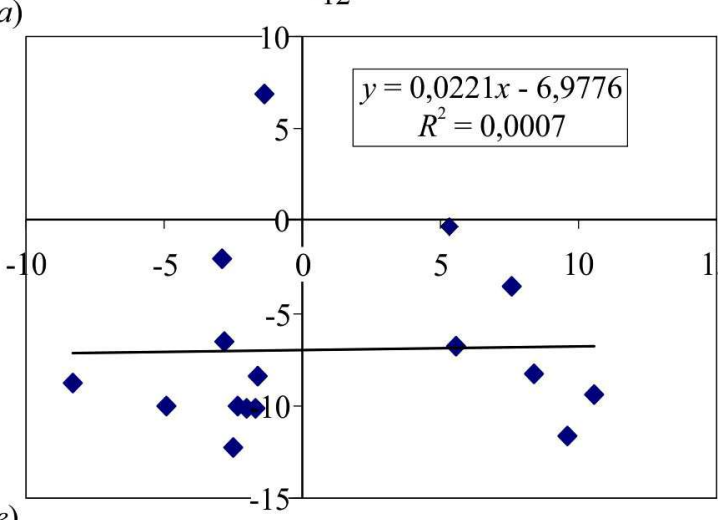

6)

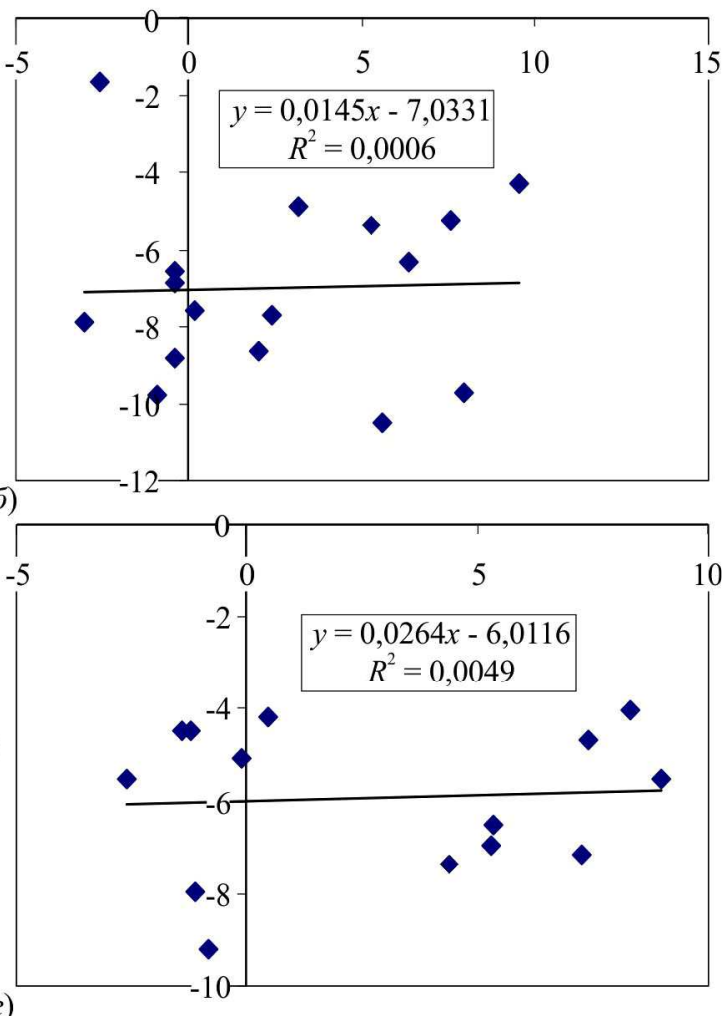

Рис. 7. Залежність структурного сальдо бюджету від припливу капіталу: $a$ ) країни "люксембурзької" групи; б) країни "хельсінської" групи; в) країни Балтії; г) країни Південної Європи. Джерело: власні розрахунки

Висновки. Проведене дослідження засвідчує досить сильний обернений зв'язок між припливом капіталу i сальдо бюджету. Поліпшення сальдо фінансового рахунку на $1 \%$ від ВВП позначається погіршенням сальдо бюджету приблизно на $0,25 \%$ від ВВП для країн ЦСЄ і Південної Європи. Для країн Балтії подібна залежність вдвічі слабша. Підвищення ставки LIBOR супроводжується поліпшенням сальдо бюджету досліджуваних країн (окрім Балтії). В обох випадках функціональна залежність зникає в разі використання структурного сальдо бюджету (з урахуванням циклічної позиції ВВП), що можна розглядати ознакою проциклічності потоків капіталу. Для нейтралізації надмірного припливу-відпливу капіталу, що так чи інакше впливатиме на фіскальні показники, необхідні заходи координації фіскальної політики на обох рівнях - національному і наднаціональному.

\section{References}

Barrell, R., Holland, B., \& Hurst, I. (2012). Fiscal multipliers and prospects for consolidation. OECD Journal: Economic Studies, 1, 71-102.

Christou, C., \& Moulin, L. (2008). Retooling Romanias budget culture. Romania: Selected Issues: IMF Country Report № 08/210, (pp. 47-60). Washington: International Monetary Fund.
Darvas, Z. (2009). The impact of the crisis on budget policy in Central and Eastern Europe. Brussels: Bruegel University, 59 p.

DeLong, B., \& Summers, L. (2012). Fiscal Policy in a Depressed Economy. Brookings Papers on Economic Activity, 233-234. Washington: The Brookings Institution.

Lewis, J. (2009). Fiscal Policy in Central and Eastern Europe with Real Time Data: Cyclicality, Inertia and the Role of EU Accession: DNB Working Paper № 214. Amsterdam: De Nederlandsche Bank, $27 \mathrm{p}$.

Manasse, P. (2007). Deficit Limits and Fiscal Rules for Dummies. IMF Staff Papers, 54(3), 455-473.

Obstfeld, M., \& Rogoff, K. (1995). Exchange Rate Dynamics Redux. Journal of Political Economy, 103(3), 624-660.

Schneider, O., \& Zapal, J. (2005). Fiscal Policy in New EU Member States: Go East, Prudent Man!: CESIFO Working Paper № 1486. Munich: Ifo Institute for Economic Research, $29 \mathrm{p}$

Shevchuk, V. (2008). International Economics: Theory and Practise. Kyiv: Znannya. [In Ukrainian].

Weber, R., \& Taube, G. (1999). On the Fast Track to EU Accession: Macroeconomic Effects and Policy Challenges for Estonia: IMF Working Paper № 99/156, (pp. 1-41). Washington: International Monetary Fund.

World Economic Outlook. (2008). Housing and the Business Cycle, April, 2008. Washington: International Monetary Fund, 282 p.

R. I. Kopych

Ivan Franko National University of Lviv, Lviv, Ukraine

\section{THE IMPACT OF CAPITAL FLOWS ON THE BUDGET BALANCE OF EUROPEAN PERIPHERY}

An important element of the fiscal policy research for the countries of European Union is the link between capital flows and the balance of the budget, including the characteristics of the interaction of its largest and periphery countries. Dependence on capital flows and balance of payments constraints is assumed to increase with increasing of economic integration, which has a relatively independent effect on fiscal policy. At the same time, the deepening of integration leads to the unification of the most common fiscal policy parameters, such as the budget balance and the level of public debt, which facilitates the harmonization of fiscal policy at the level of integration union. Specificity is determined by the exchange rate system, and above all by the ability of countries with a fixed 
exchange rate to automatically balance the payments. Using annual data for the period of 1990-2018, a relationship between the budget balance and capital flows and LIBOR is analyzed. It is demonstrated that capital inflows lead to worsening of the budget balance of the European periphery. As the relationship disappear if account for the business cycle, it is an argument in favour of the procyclicality of capital flows. In order to counteract the excessive inflow-outflow of capital that will affect in one way or another fiscal performance, fiscal policy coordination measures at both levels, national and supranational, are required. The analysis of Baltic countries and Southern European countries shows that there are radical differences between two groups of countries in the EuroPacific periphery regarding the relationship between capital flows and fiscal policy. In the run-up to the 2008-2009 financial crisis, Baltic countries had no problems maintaining a low budget deficit and with public debt, but this did not prevent the emergence of a sudden stop of capital flows. On the other hand, in Southern European countries, even the emergence of a debt crisis (with the threat of default) did not lead to a contrasting capital outflow. Capital inflows declined gradually, which showed an orderly alignment of the balance of payments - against the backdrop of solving fiscal and other problems.

Keywords: fiscal police; budget deficit; capital mobility; LIBOR; Central European countries. 